し，土壤をみたしたシャーレをほぼ垂直に立てて地表と ふたの間で浴光下においてソバの根を 36 時閒伸長させ, 土壤中の NIP の検定を行なつた。その結果, 検出され た NIP は 2〜100 ppmw [NIP (mg)/乾土 1,000 (g)] であり，根の伸長を $50 \%$ 阻害する土中 NIP の濃度は $10 \mathrm{ppmw}$ であつた。

\section{引用 文 献}

1）荒井正雄・宮原益次・片岡孝義：水田用低魚毒性除草剈の土㙥中の
残效期間と移動程度について. 雑草研究 5, 90 95 (1966).

2）古谷勝司・荒井正雄 : Diphenylether 系除草剂の作用性汇関す る研究. 雑草研究 5, 99 104 (1966).

3）野田健胃・奖木和典・小沢啓男：除草剤の作用力の温 度飞上る变 動. 雑草研究 4, 127 131 (1965).

4) PARKER, C. : Methods for the rapid bioassay of herbicides, Proc. 7 th Br. Weed Control Conf., 899 902 (1964), in "Weed Abstracts, 14 (4), 226 (1965)".

5) PARKER, C.: The importance of shoot entry in the action of herbicides applied to the soil. Weeds $14(2)$, $117 \sim 121$ (1966).

6）竹松哲夫：除草剂の生物検定法 [古山清・菅原寬夫編：農薬の生物 検定法 南江堂)], 45 67 (1965).

\title{
A Bioassay Method of NIP (2,4-Dichlorophenyl-4'-nitrophenyl ether, Nitrofen) in Soil
}

\section{Shizuo ÔMI}

Faculty of Education, Kanazawa University, Kanzawa, Ishikawa

\section{Summary}

In order to develop a sensitive and simple bioassay method for evaluating the phytotoxicity of NIP in soil, tests were conducted to determine the relative sensitivity of rice plant (Oryza sativa L.), wheat (Triticum aestivum L.), barnyard millet (Panicum crus-galli L. var. frumentaceum Hook. f.), radish (Raphanus sativus L.), Chinese cabbage (Brassica pekinensis Rupr.), cucumber (Cucumis sativus L.), and buckwheat (Fagopyrum esculentum Moench) to NIP in laboratory, and buckwheat was found to be the most sensitive of all the plant species tested.

Newly developed bioassay method of NIP in soil was based on the measurement of primary root length of buckwheat seedlings in Petri dishes in a nearly vertical position after 36 hours. Petri dishes are filled with treated or untreated soil and buckwheat seedlings are grown across the soil surface and in contact with their lids in the light.

Using this method, it was found that the concentration of NIP in soil required to give $50 \%$ reduction of the primary root growth of buckwheat was $10 \mathrm{ppm}$ (by weight), and the range of concentration detected by the method was $2 \sim 10 \mathrm{ppm}$.

\section{除草剤 propanil (DCPA) のイネおよびタイヌビエの}

\section{水分代謝と光合成とに及ぼす影響*}

\author{
農林省農業技術研究所・石川県農業試験場 $* *$ \\ 中村 拓・小泉順三**・松中昭一
}

\section{1. 緒言}

Propanil (DCPA, 3', 4'-dichloropropionanilide) が イネとノビェその他の雑草との間で顕著な選択性を示す
ことは著名な事実であるが25)，その作用機作括よび選択 性の機構に関して数多くの研究が行なわれてきた $7,9,10$, ${ }^{16,17)}$ 。この除草剤は, 土壤施用の効果が少なく, 茎葉処。 理で接触型の害徴を表わす。散布された薬剤はその場所

\footnotetext{
* 本報告の大要は昭和 42 年 4 月, 日本雑草防除研究会第 5 回講演会で発表した。
} 
にとどまり，植物体内での移行はほとんどないことが見 いだされている14,31)。選択性機構の一つとして，イネ 生体内では浸透した propanil が酵素（aryl-acylamine amidohydrolase, EC $3 \cdot 5 \cdot 1 \cdot a)$ につて 3,4-ジクロ ルアニリンとプロピオン酸に加水分解されるが，ヒエで はとの解毒能力が非常に弱いためであるという説が提出 されている1,2,11,12,13,15,19,26.27,28)。また, 軟弱徒長した イネは薬害を生じやすいこと ${ }^{6,18,22)}$, 乳凧の製剤法の差 により選択性の幅が变動することなどから ${ }^{17,22)}$, 薬剤の 侵入の難易も薬効発現に関係の深いことがうかがわれ る。実際，イネ・ヒエ間で propanil の侵入速度の異な ることが報告されている1,14)。

Propanilの作用機作としては, 他のアニリド系除草剂 と同椂に葉緑体に和ける HILL 反応の阻害が知られてい $ろ^{5,8,20)}$ 。ホウレンソウ葉緑体を用いた場合, HILL 反応 を $50 \%$ 阻害する濃度は $2.5 \times 10^{-6} \mathrm{M}$ と測定されてい

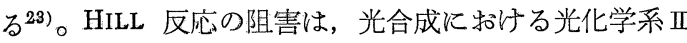
の阻害を意味し, したがつて光合成阻害をひき起こし, これが植物体を枯死させるといわれている ${ }^{3,4,5,7,20)} 。 一$ 般に, 光合成阻害が除草剤の第一次作用点である場合に は, 同化産物の欠乏による飢餓が原因となつて枯死に至 るので, 薬效が発現するまでに比較的長時間を要するの を特徵とする。しかしながら, propanilは処理後急性の 害徵を生ずることから，光合成阻害以外にも急激な作用 があるものと思称るるこの除草剤をタイスビエ等に散 布したあと観察すると，あたかも膨圧を失なつて脱水さ れたようになり，暗緑色や褐色の斑点を生じて萎淍す る。明らかに水分の均衡に異常を生ずるものと考觉られ る。

以上のような観点から，本報では，propanil作用機作 解明の一環として, propanil散布によつてイネ执よびタ イヌビェの水分代謝すなわち含水量・吸水能・蒸散能な らびに光合成能がどのような影響をうけるかを検討した 結果を報告する。

本研究の光合成扣よび蒸散測定にあたつては, 当研究 所・生理第 1 研究室より種々援助をあ扣いだ。ここに, 同研究室長 宮坂 昭技官, ならびに使用時, 懇切な指 導と助言とを与えられた秋田重誠拉よび本間 力両技官 《感謝の意を表わすものである。

\section{2. 実 験 方 法}

\section{（1）葉の含水量測定}

$600 \mathrm{~m} l$ ポリエチレンビーカーに水田土壤を詰め, これ に催芽したイネ（農林 29 号, 以下同様）执よびタイヌ どェを 1 ポットあたり 25 粒あて播種した。両植物とも
その 3 葉期に, $0.5 \%$ の propanil 乳化液をコンプレッ サーに連結したペーパークロマトグラフィ用噴霧器で散 布した（1966 年 8 月 26 日）。散布後, 日中は晴天の野 外に置き, 一定時間招さに 2 ポット分の全本葉を採取し その水分含量を測定した。経過期間中の気温は平均 25 ${ }^{\circ} \mathrm{C}$ 前後であつた。

\section{（2）吸水能測定}

土耕法で生育させた 4.5 葉期のイネおよびタイヌビェ を, 根を切らぬように注意して水洗し, 水道水を満し たポトメーターに 2 本ずつそら入した。植物体を水耕に 馴化させるため, そのまま室内で 1 日間放置したあと， 晴天の日の自然条件下で吸水能を測定した。ポトメータ 一の根部は遮光し, $18 \pm 1^{\circ} \mathrm{C}$ に保つた。吸水測定にあた つては，あらかじめ吸水能のほぼ等しい材料を選んで抹 き，その一つに $1.0 \%$ propanil 乳化液を散布したあと, 30 分ごとに吸水量を体積測定した。なお，この実験で は, 非選択性で速効性の除草剤 paraquat の $0.3 \%$ 水 溶液を同様に処理して比較対照とした。

\section{（3）蒸散および光合成測定}

$600 \mathrm{~m} l$ ポリエチレンビーカーに土耕法でイネ拈よびタ イヌビェを均一に育て（1 ポットあたり 20 本），それら の 3.0 葉期に所定濃度の propanil 乳化液を散布し, そ の後経時的に蒸散括よび光合成を, 当研究所生理第 1 研 究室試作の “幼植物用光合成・蒸散同時測定装置” を使 用して同時測定した ${ }^{21)}$ 。装置設定条件は, 照度 40 キ口 ルックス, チャンパー内温度 $28 \sim 30^{\circ} \mathrm{C}$, 蒸散測定用サ 一ミスタ一乾湿球部の風速 $2.3 \mathrm{~m} / \mathrm{sec}$, 通風速度毎時 100 $l$ とした。Propanil の散布濃度は $0.1 \%$ 牤よび $1.0 \%$ とし, 前者は 1966 年 9 月 14 日, 後者は 9 月 22 日に散 布し，1区あたり 2 ポットを供試測定した。それぞれ， 第 1 日目の測定終了後, 第 2 日目以降の測定時（正午前 後の約 1 時間）以外は，ポットを戸外に放置した。

\section{3. 実 験 結 果}

\section{（1）葉の水分含有率に及ぼす影響}

Propanil 散布が，イネ括よびタイヌビェの葉の水分 含有率にどのように影響するかを調べた結果が第 1 図に 示される。タイヌビェでは, propanil散布直後から 1 日 以上, 水分含有率が無処理に比べて $2 \sim 3 \%$ 程度高まつ た。しかし, 散布 48 時間後には急激に低下して和り, このころには肉眼でも害徴の発現が観察される。イネに 括いても propanil 散布により水分含有率が 1 ～ $2 \%$ 増 加するが，48 時間後には無処理との差がなくなつた。 この実験は数回反復されたが，薬剂散布後一時水分含有 率の高まる現象は常に観察された。 


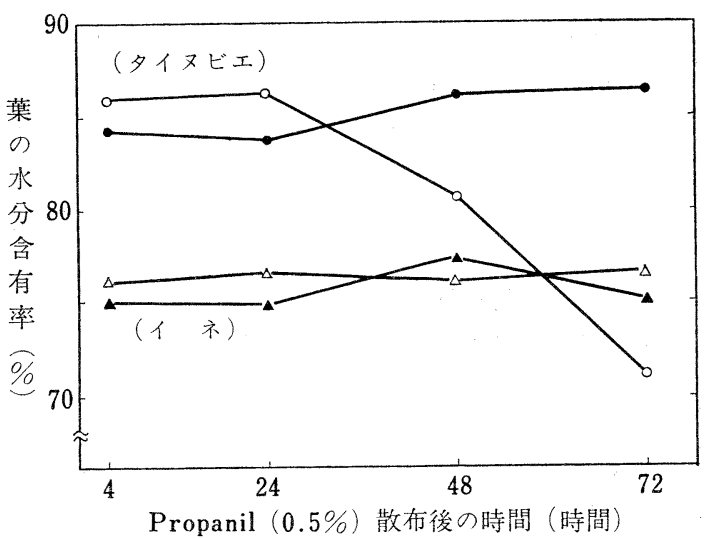

第 1 図Propanil 散布後の葉の水分含有率の変化

注）タイヌビェ：・無処理区, ○散布区

*：、無処理区, $\triangle$ 散布区

\section{（2）吸水能に及ぼす影響}

Propanil を散布すると，イネ，タイヌビエともに吸水 速度が急激に低下した（第 2 図）。イネでは時間経過と そもに回復してくるが，タイヌビェでは回復することな く低下し続け, 散布後 1 時間で無処理の $1 / 4$ 程度となり, 日変化も小さくなる。非選択性除草剤 paraquat は両植 物間で大差なく，一方的に吸水速度を低下させる（第 2 図)。処理翌日になると, propanil 処理のイネの吸水能 力は, 無処理とほぼ同じレベルまで回復するが, タイヌビ エならびに paraquat 処理のイネ招よびタイヌビエによ

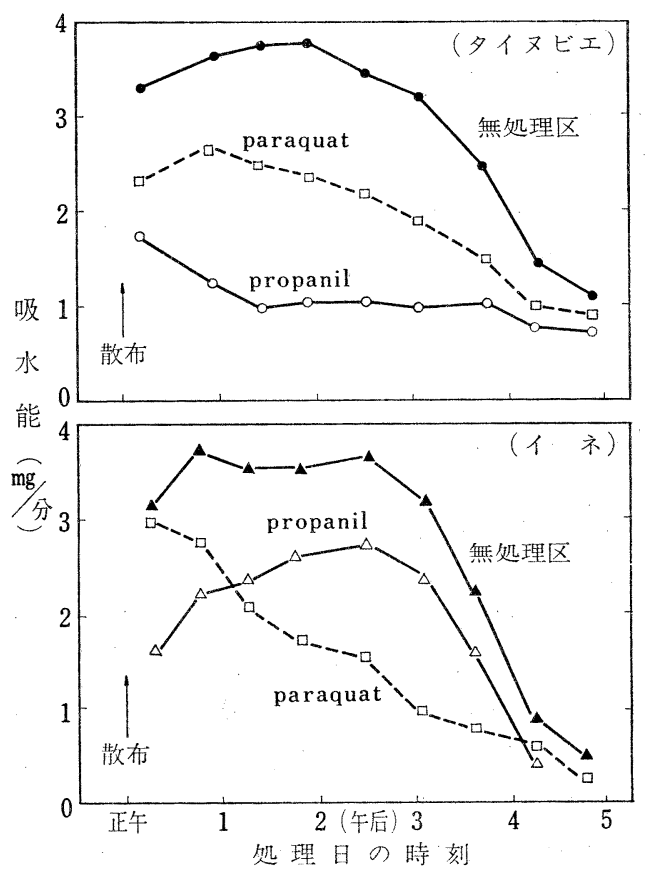

第 2 図Propanil 散布後の吸水能の変化（処理当日）

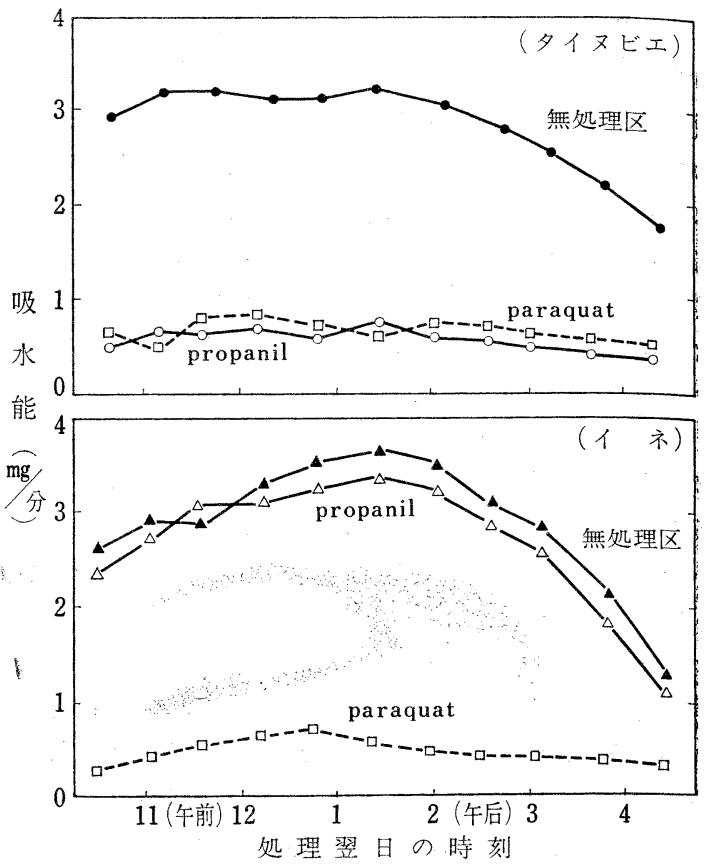

第 3 図Propanil散布後の吸水能の变化(処理翌日)

る吸水は低下したますで日变化もほとんどなく，ほぼ物 理的吸水の反を示しているものと考兄られる（第 3 図)。

\section{（3）蒸散および光合成に及ぼす影響}

第 4 図には, propanil 散布区の蒸散能および光合成能 が，各測定時に却ける無処理区のそれにたいする百分率 で示されている。無処理区の蒸散能の絶対值は, イネで $2.7 \sim 2.9 \mathrm{~g} / \mathrm{hr}$. $/$ pot, タイヌビェで $2.0 \sim 2.1 \mathrm{~g} / \mathrm{hr}$. $/$ pot 程度であつた。Propanil 散布区の蒸散能は, イネでは 24時間後には回復がみられたが，タイヌビェでは低下す る一方で，回復はみとめられなかつた。

ここでいう光合成とは炭酸ガス固定量で, 測定したみ かけの光合成を意味するが，その無処理区での絶対值は イネでは $6.6 \sim 6.9 \mathrm{mgCO} / \mathrm{hr}$./pot，タイヌビェでは 7.6 $\sim 7.9 \mathrm{mgCO} / \mathrm{hr}$. $/$ pot 程度であつた。第 4 図下半分に示 すように, propanil散布直後より光合成能は急激に阻害 され，30 分後にはイネ・タイヌビエともに完全にその 光合成を停止した。その後, イネでは， $0.1 \%$ 散布区が 翌日から，1.0\% 散布区では翌々日から部分的な回復が みとめられ，3〜4日経過すると，両処理区とすほぼ完全 に回復した。一方, タイヌビェでは両処理区とる全く回 復を示さず，結局枯死した。

\section{4. 考察}

除草剤処理による植物の葉の水分含有率の上昇と蒸散 能の低下については, atrazine に関する WILLS 等 ${ }^{30)}$ 

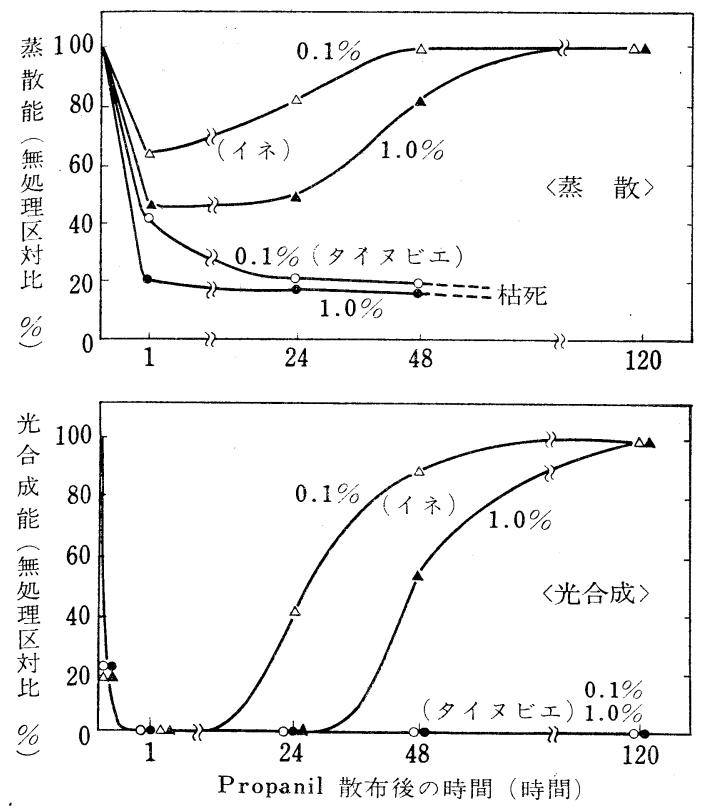

第4図 Propanil散布がイネ拈よびタイヌビェの 蒸散能および光合成能に及ぼす影響

注）○・はタイイヌビエ, $\triangle \boldsymbol{\Delta}$ はイネ；\%は propani1散布濃度

SMITH 等 ${ }^{24)}$ の報告がある。彼等はその理由として気孔 の閉塞をあげている。Propanilの場合も気孔への影響が 考兄られるので, スンプ法29) 特よび浸潤法 ${ }^{29)}$ で調べた が，気孔の閉塞を確認するには至らなかつた。イネでは 光合成を完全に停止したまま，かなりの蒸散を行なつて いる時期のあることも観察されているので, propanil 処 理は気孔の開度にはあまり大きい影響を与えないように 考觉られるが，この点は実験方法の改良により確認した W。

実験結果が示すように, propanil 散布により, 水分 代謝和よび光合成は, イネ, タイヌビエ両植物ともに急 激な阻害を受ける。タイヌビェではこの阻害が進行し て回復しないのに対し、イネではいずれの阻害も回復す る。

イネに和ける回復現象を, 水分代謝と光合成とで比較 すると, 水分代謝の回復のほうが光合成上り速やかに行 なわれ，とくに吸水能力の回復は速やかである。このこ とは, propanil の作用点が HILL 反応以外飞もあること を示唆するようである。すなわち, イネは水分代謝に及 ぼす propanil の作用に耐光た後, 体内の解毒醅素によ り散布後 1 3 日間で propanil を加水分解・無毒化し, 光合成能を回復させるのであろう。これにたいし，タイ ヌビエに怙いては, propanil散布により水分代謝に影響 を与えるような異常（たとえば, 原形質タンパクの变性 や細胞膜機能の破壊などが想定される）を生じ, 光合成
の阻害と相まつて, 枯死に至るものと推測される。

したがつて、イネが propanil にたいして示す抵抗性 機構を考光るとき，その加水分解醰素による propanil の解毒とともに，本実験で水分代謝阻害としてとらえら れた散布直後の propanil の直接的な作用にも抵抗的で ある点にも注目すべきであろら。裏がえしていうなら ば, タイヌビエがたと党 propanil 解毒酵素をもつてい たとしても初期の作用に耐えられないので propanil に 抵抗性を示さないと想像され，これらのことから，propanil の第一次作用点の追求にあたつては, この散布直 後の直接的な作用を重視しなければならないことが示唆 されている。

\section{5. 要 約}

Propanil の作用機作を明らかにするために, propanil 散布がイネ扣よびタイヌビエの水分代謝叔よび光合成に どのように影響するかを検討した。

Propanil 散布後, イネ・タイヌビェともに一時葉の水 分含有率が高まつた。その後, タイメビエに拈いては急 激に脱水されるが，イネは回復して無処理区と同じレベ ルとなつた。吸水能拉よび蒸散能は, propanil 散布直 後より両植物とも急激に低下した。イネに扣いては, 処 理後 1 時間で無処理区の $70 \%$ 程度に, 翌日になると完 全に回復したが，タイヌビエに呿いては低下したままで あつた。

光合成能は,イネ・タイヌビェともに処理直後から完 全に停止した。イネに怙ける光合成は漸次回復したが, その回復は水分代謝阻害のそれよりはかなり特くれ， 3 〜 5 日後に無処理区と同程度となつた。一方, タイヌビ エでは全然回復を示さず枯死した。

Propanilの作用機作としては, 光合成能を強く阻害す ることが見いだされたが，これ以外に，本実験で散布直 後の水分代謝阻害としてとらえられた直接的な作用も重 要であることがみとめられた。イネが propanil に対し て抵抗的な理由として, 解毒醏素による無毒化以外に, この初期の直接的な作用に抵抗的であることにも注目す る必要があろう。

\section{参考 文 献}

1）足立明朗・利根川和江・上島俊治：農薬生産技術 14, 19 (1966).

2) 足立明朗・利根川和江・上島俊治 : 農薬生産技術 15, 11 (1966).

3) Cooke, A. R. : Weeds 4, 397 (1956).

4) Gentner, W.A. and L. Hilton: Weeds 8, 413 (1960).

5) Good, N.E. : Plant Physio1. 36, 788 (1961).

6) 原田哲夫・江户義治 : 雑草研究 1,96 (1962).

7) Hofstra, G. and C.M.Switzer : Weed Science 16, 23 (1968).

8) Huffman, C. W. and S.E. Allen: J. Agr. and Food Chem. 8, 298 (1960). 
9) Inoue, Y., K. Ishizuka and S. Mitsui : Agr. Biol. Chem. (Tokyo) 31, 422 (1967).

10）井上頼直・石塚艁造・三井進午：日本農芸化学会報告 43, 249(1968).

11）石塚皓造・三井進午 ：日本宸芸化学会報告 41, 62(1966).

12）石塚皓造・吉田允子・三井進午：日本農芸化学会報告 42, 47(1967).

13) 石塚皓造・吉田允子・兰井進午：日本農芸化学会報告 43, 249(1968).

14）石塚皓造・大塩裕陸・三井進午: 日本土壤肥料 学会報告 12,53 (1966).

15) ·伊藤 堯・利根川和江・上島俊治 : 雑草研究 6,71 (1967).

16）近内誠登：日本作物学会紀事 30,361 (1962).

17) 近内誠登・一前宣正・高橋善郎 : 杂隹草研究 6, 74 (1967).

18）九州農業試験場作物第 5 研究室 昭和 42 年度試験成績書 (1968).

19) MCRAE D. H., R. Y. YIH and H.F. WILsON : Abstracts, WSA 87 (1964).

20) Moreland, D.E. and K. L. Hill: Weeds 11, 55 (1963).
21）農業技術研究所生理第 1 研究室 昭和 40 年度試験成績書 (1966).

22) 農業技術研究所生理第 5 研究室 昭和 38 年度試験成績書 (1963).

23) 農業技術研究所生理第 6 研究室 昭和 42 年度試験成樍書 (1968).

24) Smith, D. W. and K. P. Buchнoltz: Science 136, 263 (1962).

25) Sмith, R.J. Weeds 9, 318 (1961).

26) Still. C.C. and O. Kuzirian : Nature 216, 799 (1967).

27) Still, G. G. : Science 159, 922 (1968).

28) Still. G.G. and D.S. Frear : Abstracts, Am. Chem. Soc. (1968).

29) 植物生理学実習 (北大理学部植物生理学教室編) 養賢堂, 67(1955).

30) Wills, G. D., D.E. Davis and H. H. Funderburk, Jr. : Weeds 11, 253 (1960).

31) Yamada, N. and H. Nakamura : Proc. Crop Sci. Soc. Japan 32, 69 (1963).

\title{
Effects of a Herbicide, Propanil, on Water Metabolism and Photosynthesis of Rice Plants and Barnyardgrass
}

\author{
Hiroshi Nakamura, Junzo Kolzumi*, and Shooichi Mastunaka \\ National Institute of Agricultural Sciences, Konosu, Saitama, and * Ishikawa \\ Prefectural Agricultural Experiment Station, Nonoichi, Ishikawa
}

\section{Summary}

The effects of propanil on water metabolism and photosynthesis of intact rice plants and barnyardgrass were examined to investigate the primary action of the herbicide. The moisture content in leaves of both propanil-sprayed rice plants and barnyardgrass was higher than that of the checks soon after the foliar application. In barnyardgrass, the moisture dropped sharply when visible symptoms appeared, wheras in rice plants it restored to the level of the check, and no visible evidence of damage was observed throughout the experiments. Both water uptake and transpiration of these two species were severely reduced immediately after the treatment. These reductions in rice plants were recovered to a level of 70 per cent of the check one hour after the spraying, and their water uptake and transpiration reached to almost the same level as the untreated plants one day after the treatment. On the other hand, barnyardgrass did not show any recovery.

Photosynthesis of either rice plants or barnyardgrass was inhibited completely whithin half an hour after the spraying of propanil. The inhibition in rice plants was recovered, but the recovery delayed as compared with those of water uptake and transpiration. The barnyardgrass died without any recovery of photosynthesis.

From these results it may be concluded that, as the primary action of propanil, the drastic action which appeared as the inhibition of water metabolism should be mentioned in addition to the inhibition of photosynthesis. 